\title{
Riglyne vir ' $n$ verantwoordelike Nuwe Testamentiese verstaan in die homoseksualiteitsdebat. Deel 1: 'n Komplekse Saak
}

Gert J Steyn

(Universiteit van Pretoria)

\section{ABSTRACT \\ Guidelines for a responsible New Testament understanding in the homosexuality debate.Part 1: A complex issue}

This is the first of two contributions that are asking how the New Testament can be used in a responsible manner in the debate about homosexuality. It is clear that this is a complex issue which is driven by subjective opinions about the phenomenon itself, and by the selection and analysis of passages chosen for the chosen viewpoint of the individual. Different arguments are steering the debate: emotional, societal pressure, biological-psychological, biblical, theological, and technical arguments all find their way in different contexts. The fact of the existence of deviations in nature, the occurrence of the phenomenon in different primitive and ancient cultures, and the use and application of a single term for a variety of aspects, are all contributing to this complex labyrinth. A responsible use of the New Testament in the debate on homosexuality can only happen when it is done in a diversified and qualified manner.

Die Nuwe Testament is verrassend stil oor die onderwerp van homoseksualiteit - veral in die lig van die feit dat die verskynsel wydverspreid in die Grieks-Romeinse wêreld voorgekom het. Volgens die evangelies het Jesus self niks hieroor gesê nie. Dit kan waarskynlik daaraan toegeskryf word dat Jesus se menslike leefwêreld grotendeels beperk was tot die Jodedom en tot die geografiese gebied van Galilea (Cole 1959:360). Paulus raak wel die onderwerp skrams aan (slegs ten opsigte van manlike homoseksualiteit) in sy briewe aan die Christene in Rome (Rom 1:18-32), en in sy Korintiese korrespondensie (1 Kor 6:9-11). Hierdie verwysings in die Pauliniese literatuur is waarskynlik juis daaraan toe te skrywe dat die verskynsel meer algemeen was onder die Grieke en Romeine as onder die Jode. Ook in die latere briefie aan Timoteus (1 Tim 1:10) word die onderwerp vermeld in ' $n$ lys sake waarin God 'n afkeur het. Soos later in hierdie bespreking duidelik sal word, dui die konteks van elkeen van hierdie gedeeltes egter op spesifieke vorme van homoseksuele gedrag. 
Enkele ander Nuwe Testamentiese gedeeltes word ook in die debat rondom homoseksualiteit betrek, soos 1 Tessalonisense 4:5; Kolossense 3:5; Handelinge 15:28-29 (porneia); 2 Petrus 2:7 (athesmōn); Judas 7 (ekporneusasai); Openbaring 21:8 (pornois) en Openbaring 22:15 (pornoi). Dit bied dus ' $n$ totaal van ' $n$ moontlike tien Nuwe Testamentiese teksgedeeltes wat in die homoseksualiteitsdebat gebruik word - veral deur diegene wat sterk teen hierdie verskynsel reageer. Daar is egter geen direkte verwysings na homoseksualiteit as sodanig in die laasgenoemde vyf gedeeltes nie, maar eerder breë, algemene verwysings na onsedelikheid en onsedelike praktyke. Dis twyfelagtig of hierdie gedeeltes spesifiek na homoseksuele gedrag sou verwys. Dit word wel soms in die debat bygetrek om "n groter kwantiteit van "bewysmateriaal" teen homoseksualiteit aan te voer. So, byvoorbeeld, is Judas 7 ' $n$ parallel van 2 Petrus 2:6-8 en beide gedeeltes verwys na die immoraliteit van Sodom en hoogstens na sodomie eerder as na ons moderne verstaan van homoseksualiteit (sien Swanson 1997). Dit laat ons met vyf moontlike verwysings na homoseksualiteit per se: Romeine 1:26-27; 1 Korintiërs 6:9-11; 1 Timoteus 1:10; 1 Tessalonisense 4:5 en Kolossense 3:5 - almal uit die Pauliniese literatuur.

Die vraag is dus: Wat sê die Nuwe Testament oor homoseksualiteit? Hiermee saam hang die vraag in watter vorme die verskynsel reeds in die antieke Nuwe Testamentiese tyd bestaan het. Dan sal daar gevra moet word of die verskynsel van homoseksualiteit tot dieselfde mate in die verskillende antieke kulture tydens die Nuwe Testamentiese tydvak voorgekom het en aktief bedryf was, en hoedat dit onder die Jode sou gefunksioneer het, of nie gefunksioneer het nie, omdat die Christendom hoofsaaklik as ' $n$ aanvanklike vertakking van die Jodedom ontstaan het. Die saak lê dus veel wyer as die blote verwysing na, of aanhaling van, hoofsaaklik drie tot vyf teksgedeeltes uit die Nuwe Testament - en die gepaardgaande onsekerheid of die ander verwysings oor onsedelikheid wel homoseksualiteit insluit, en indien wel, in welke vorme. Dit raak ten diepste die kultuur- of sosio-historiese agtergrond waarbinne hierdie vermelde Skrifgedeeltes beslag gekry het.

Ten einde verantwoordelik met hierdie Nuwe Testamentiese teksgedeeltes om te gaan, wil hierdie bydrae dus poog om die verskynsel van homoseksualiteit ietwat wyer te bekyk. Daar gaan veral op drie aspekte gefokus word: Eerstens gaan gevra word hoe 
die debat tans daar uitsien. Tweedens gaan daar gekyk word na die kompleksiteit van die verskynsel van homoseksualiteit en die potensiële gevare in die hantering van hierdie aangeleentheid. Hier gaan dit nodig wees om kortliks ook te kyk na die kultuurhistoriese agtergrond, of die sosiale konteks, waarbinne die moontlike verwysings na homoseksualiteit in die Nuwe Testament verstaan behoort te word. Beide hierdie sake word in Deel I van hierdie studie aangespreek. Laastens gaan daar teen hierdie breë sosiale agtergrond na die vyf vermelde gedeeltes in die Nuwe Testament gekyk word wat gebruik word in die argumente rondom homoseksualiteit. Dit word in Deel 2 hanteer. Die doel is om uiteindelik verantwoordelike riglyne uit die Nuwe Testament te formuleer wat dan kan dien as rigtingwysers in die huidige debat, juis omdat die Nuwe Testament normatiewe Skrif is vir Christengelowiges.

\section{HOE LYK DIE HUIDIGE TONEEL?}

\subsection{Denkrigtings en standpunte}

Ten diepste handel dit in die homoseksualiteitsdebat oor menslike gedrag. Die saak is dus in sy wese ' $n$ etiese aangeleentheid. Net soos ander etiese sake (bv aborsie, genadedood, orgaanoorplantings, ens) verskil die omstandighede van geval tot geval sodat dit nie so eenvoudig is om 'n kategoriese "vir" of " $n$ "teen" standpunt te formuleer wat in álle gevalle, onder álle omstandighede, in álle plekke, op álle persone en oor álle tye sonder kwalifikasie of konteks van toepassing is nie. Nogtans word die homoseksualiteitsdebat grootliks gekenmerk deur twee basiese opponerende en gepolariseerde denkrigtings. Vir sommige is dit sosiaal-onaanvaarbare gedrag in alle gevalle, onder alle omstandighede, vir alle persone oor alle tye en word christelik-etiese argumente gesoek om dit af te keur en die betrokkenes as "skuldig" te verklaar - selfs soms eintlik "God te speel" in die veroordeling van homoseksueel-georiënteerde persone. Hierdie denkrigting weerspieël soms 'n homofobiese polemiek. Geyser (2002:1655) wys daarop dat hierdie groep "hulle beroep (op) 'duidelike uitsprake' in die Skrif”. Vir ander weer is dit sosiaal-aanvaarbare gedrag, of minstens tolereerbare gedrag, in alle gevalle, onder alle omstandighede, vir alle persone oor alle tye en word daar ook hier na christelik-etiese argumente gesoek om hulle standpunt te onderskryf. Hierdie groep redeneer hoofsaaklik vanuit humanistiese oorwegings (Geyser 2002:1655). Die debat ontaard dus grootliks in ' $\mathrm{n}$ Bybelse getoutrekkery, in die soeke en lys van 
toepaslike teksgedeeltes en in die karrikaturing van die opponerende standpunt. Beide standpunte beroep hulle op die "Heilige Skrif" en so ontstaan daar verwarring oor wat die Bybel nou regtig hieroor te sê het. In sy diepste wese weerspieël die debat dus die subjektiwiteit van Bybelverstaan (hermeneutiek).

Binne hierdie twee opponerende denkrigtings, is daar vier duidelike basiese standpunte wat in die debat geïdentifiseer kan word: twee sterk gepolariseerde menings en twee minder verteenwoordigende genuanseerde menings. Dit sou geïllustreer kon word met ' $\mathrm{n}$ lyn waarop $\mathrm{A}$ en $\mathrm{D}$ in opposisie teenoor mekaar staan, met $B$ en $C$ wat onderskeidelik verder van die twee pole lê en nader aan mekaar:
A
B
C
$\mathrm{D}$

Hierdie standpunte sou soos volg opgesom kon word:

A. Dis ongekwalifiseerd "Okay to be gay". Voorbeelde van hierdie standpunt kry gestalte in die stigting van gay gemeentes soos wat lank gelede reeds in die VSA gebeur het.

B. Dis gekwalifiseerd “Okay". Persone wat so gebore sou wees of wat in ' $n$ enkele getroue en verantwoordelike verhouding betrokke is, is aanvaarbaar.

C. Dis gekwalifiseerd verkeerd. Hier moet òf die "sonde veroordeel word, nie die sondaar nie”, òf die feit van homoseksualiteit word erken, maar "aktiewe homoseksuele gedrag” kan nie geduld word nie.

D. Dis ongekwalifiseerd verkeerd en is sonde. Sommige gaan selfs so ver om dit te sien as "n bose "demoon" wat uitgedryf moet word en glo dat hierdie gedrag eenvoudig verander kan word deur bekering.

\subsection{Argumente wat gebruik word}

Ten einde die standpunte hierbo te motiveer, word verskillende argumente aangevoer:

- Emosionele argumente: Gewoonlik word die huidige homoseksualiteitsdebat gekenmerk deur baie swaar emosioneel gelade argumente wat die gepolariseerde denkrigtings wil dryf as die enigste betroubare waarhede. Dis nie soseer die inhoud 
van die argumente wat die debat in bepaalde rigtings stuur nie, maar eerder die vorm waarin die inhoud aangebied word, naamlik die krag van die emosie waarmee hierdie argumente verwoord word. In sommige kerkvergaderings dink mens byna onwillekeurig aan die destydse oproer in Efese waarvan Lukas in Handelinge 19:32 skryf: "Almal het deurmekaar geskreeu, en die hele vergadering was in die war". Daar word nie na mekaar geluister nie. Rasionaliteit, verantwoordelikheid, sensitiwiteit en diversiteit verdwyn spoedig in gesprekspogings. Die oorheersende gevoel van die gesprek word een van futiliteit "omdat dit dreig om in 'n doodse sirkelredenasie vasgeval te wees” (Geyser 2002:1655).

- Sosiale druk: Enersyds dreig kerklidmate om die kerk te verlaat as die kerk nie 'n duideliker standpunt oor hierdie saak wil formuleer nie soos blyk uit verskeie informele gesprekke. Predikante in gemeentes wat direk afhanklik is vir hulle persoonlike oorlewing in sodanige gemeentes word deur hierdie sosiale druk dikwels na die D-standpunt hierbo gedryf. Andersyds oefen ook die breër gemeenskap dikwels druk uit op soek na antwoorde. Soms is die kerke se hantering van die homoseksualiteitsdebat weer ' $n$ sein dat daar nie plek is vir homoseksuele persone in die kerk nie en vervreem hulle van hulle geloofsgemeenskappe. Daar is dus sosiale druk na beide kante van die spektrum en word hierdie sosiale druk die inhoud van die argumentvoering. Dit plaas kerke onder groot druk om so vinnig moontlik finale uitsprake in hierdie verband te gee. "Die kerk moet nóú besluit of homoseksualiteit sonde is of nie”, word daar gesê. Dis waarskynlik hierdie sosiale druk wat uiteindelik die belangrikheid van die debat vir die kerk op hierdie stadium bepaal.

- Biologies-psigologiese argumente: Die stokou debat oor die feit tot watter mate menslike gedrag altyd aangebore of aangeleer sou wees, word ook in die bespreking oor homoseksualiteit gebruik as ' $\mathrm{n}$ argument. Dit wil voorkom asof die feit dat sommige persone wel homoseksueel gebore kan word, nie vandag meer wyd ontken word nie. Die feit dat hierdie gedrag ook onder bepaalde aapsoorte voorkom versterk hierdie standpunt. Daar blyk ook genoegsame bewyse uit gevallestudies te wees dat verskeie persone weer homoseksuele 
gedrag vertoon as gevolg van persoonlike psigologiese en sosiale omstandighede waaraan hulle blootgestel was.

- Bybelse argumente: Vir Christengelowiges wat die Bybel as normatief aanvaar vir hulle lewens, is dit uiteraard baie belangrik om in die Bybel te soek na antwoorde op etiese vraagstukke. Daar is reeds hierbo verwys na die feit dat verteenwoordigers van beide kante van die spektrum in die homoseksualiteitsdebat hulle daarop beroep dat "Die Heilige Skrif sê...”. Teksverse word dan aangehaal en gebruik na beide kante toe. Die debat word dan 'n klassieke voorbeeld van hoedat die Skrif verstaan en geinterpreteer, gebruik of misbruik word. Die groep wat hierdie sosiale verskynsel onaanvaarbaar vind, is afkeurend en weerspieël 'n toegeneentheid tot ' $n$ meer histories-letterlike lees van tekse wat moontlik na hierdie verskynsel - binne ' $n$ hedendaagse verstaan van homoseksualiteit! - sou kon verwys. Die ander groep wat hierdie sosiale verskynsel aanvaarbaar vind, werk weer met hulle eie seleksie van Bybelse tekste vanuit 'n breër teologiese of etiese invalshoek.

- Teologiese argumente: Verskillende gekwalifiseerde teologiese argumente word ook in die homoseksualiteitsdebat gebruik, byvoorbeeld die daad is verkeerd, maar die "sondaar" moet aanvaar en liefgehê word; of dis "okay” om gay te wees, maar die praktisering daarvan is verkeerd. Hierdie is dan riglyne wat uit ' $n$ bepaalde lees van die Nuwe Testamentiese dokumente geformuleer word.

- Tegniese argumente in vergaderings oor vergaderingsprosedures word uiteindelik die laaste strategie in die oorlog. Partye beroep hulle sterk op vergaderingsprosedures, op voorstelle, amendemente op voorstelle en revisies van voorstelle ten einde hulle standpunte af te dwing. Dis byna asof die meerderheidstem by ' $\mathrm{n}$ kerkvergadering sou kon bepaal of sekere gedrag sonde is of nie.

\section{KOMPLEKSITEIT EN GEVARE IN DIE DEBAT}

\subsection{Die gegewendheid van afwykings}

Daar is verskeie kontrasterende teorieë vir die oorspronge van homoseksuele gedrag (Morris 1979:503). Volgens sommige kan die oorspronge hiervan gevind word in fisiese afwykings tydens die 
ontwikkeling van die menslike fetus, volgens andere weer, lê die oorspronge te vind in psigologiese afwykings wat die gevolg kan wees van aangeleerde gedrag of sosiale omstandighede. Hierbenewens het eksterne omgewingsfaktore soos oorbevolking waarskynlik ook ' $n$ effek op ' $n$ toename in homoseksuele gedrag.

Dis ' $\mathrm{n}$ onomstrede feit dat fisiese afwykings wel voorkom in die vorming van die mens. Dis deel van 'n gebroke skeppingswerklikheid waarin ons leef. So ontstaan daar byvoorbeeld Siamese tweelinge, persone wat gebore word met 'n derde been, met meer of minder tone of vingers, met dubbelslagtigheid, ensovoorts. Hierdie is fisiese afwykings wat nie "normaal" is teenoor hoe die oorgrote getal mense fisies lyk nie.

Maar ook gedragsversteurings wat die gevolg sou kon wees van psigologiese afwykings, kom voor by sommige mense. By sommiges blyk dit aangebore gedrag te wees, by ander weer aangeleerde of latere sosiaal-ontwikkelde gedrag. Moontlike voorbeelde sou verskillende vorme van psigotiese gedrag, depressielyers, alkoholiste en dwelmverslaafdes kon wees. Navorsing is reeds onderneem waarin genetiese predisposisioneerdheid en tekorte van die breinhormoon serotenien sterk verbind kan word met hierdie soorte gedragsvorme. Volgens Hooker (1969:140-142) - wat verskeie intensiewe studies oor die verskynsel van homoseksualiteit onderneem het - is daar ' $n$ onteenseglike duidelike verband tussen manlike homoseksuele gedrag en 'n skewe, ontwrigte of patologiese ouer-kind-verhouding in die vroeë kinderjare van hierdie persone (Morris 1979:503; Cole 1959:357). Homoseksualiteit toon van alle vorme van seksuele afwykings die grootste omvang. In die veertigerjare van die vorige eeu is alreeds vasgestel dat ongeveer ' $n$ derde van alle volwasse manlike persone in Amerika een of meer homoseksuele ervarings gehad het (Geldenhuys \& Du Toit 1979:253).

Cole (1959:356) bevestig dat ' $n$ verskeidenheid resente bydraes inligting bevat oor die feit dat daar 'n besliste biologiese basis vir homoseksuele gedrag bestaan (vgl Looy 1995:197-214; Schmidt 1995:137-142; Burr 1996:21-36). Die aard van hierdie biologiese invloede is multi-dimensioneel en sluit faktore soos die genetika, intra-uterale hormonale veranderinge en moontlike verskille in die breinstruktuur se ontwikkeling in. Daar is, byvoorbeeld, lankal reeds bewys dat homoseksuele mans beduidende laer vlakke 
van die manlike hormoon testosteroon bevat as heteroseksuele, of selfs biseksuele mans (Morris 1979:53). Aan die ander kant het die kunsmatige behandeling met geslagshormone homoseksuele gedrag gestimuleer eerder as dat dit die oriëntasie van homoseksuele persone verander het (Geldenhuys \& Du Toit 1979:256). Verskillende van hierdie biologiese faktore werk volgens Cole (1959) ongetwyfeld saam in ' $n$ finale en globale manifestering van die biologiese impak op gedrag. Daar is egter nie eenstemmigheid onder geleerdes oor die graad van hierdie biologiese invloede op homoseksuele gedrag nie. Sommige reken selfs dat alle gedrag biologies bepaald is en dat geen spesiale gewig toegeken behoort te word aan die biologiese basis van homoseksualiteit as sodanig nie (Greenberg \& Bailey 1993:245-251). So het 'n ouer studie deur Kolodny gemeen dat die tekort aan testosteroon by homoseksuele mans nie die oorsaak van hulle homoseksualiteit is nie, maar eerder die gevolg is daarvan (Morris 1979:53). Feit bly egter staan dat daar wel spesiale gewig toegeken word aan die biologiese en psigologiese oorsake van homoseksualiteit en dat hierdie empiriese gegewens nie sondermeer van die tafel afgevee kan word nie (Cole 1959:356-357). Die gegewens mag wel geïnterpreteer word dat biologiese invloede bepaalde persone mag "predisposisioneer" vir homoseksuele gedrag, eerder as dat hulle in hulle aard "bestem" is tot hierdie gedrag (Cole 1995:89-100; Morris 1979:53).

' $n$ Interessante eksperiment wat saam met sosiale afwykings in gedagte gehou moet word, is dié wat deur Calhoun onderneem was in 1962. Die studie het duidelik getoon dat "crowding", of oorbevolking, onder ' $n$ groot verskeidenheid diere daartoe gelei het dat hierdie diere bisarre gedrag begin vertoon het: moeders het hulle eie kleintjies begin eet, homoseksualiteit het skerp gestyg onder al die verskillende diersoorte en sommige rotte het onttrek in ' $n$ toestand van depressie. In alle gevalle het die diere wel genoeg gehad om te eet en te drink en hulle leefkwartiere was skoon, maar daar was 'n drastiese oorbevolking aan die orde van die dag wat gelei het tot hierdie afwykings (Morris 1979:588-589).

Die gegewenheid van biologiese, psigologiese en omgewingsfaktore wat lei tot afwykings wat sosiaal onaanvaarbaar is, noop ook Bybelse eksegete om verantwoordelik en sensitief om te gaan met uitsprake vanuit hulle bestudering van die antieke konteks van die Bybel wanneer hierdie resultate hermeneuties toegepas word in die midde van hedendaagse natuur- en sosiaalwetenskaplike kontekste. 
' $n$ Reglynige, tydlose hermeneutiek is in stryd met die besondere openbaring van die Skrif self wat eietyds en kontekstueel God se boodskap kom kommunikeer het.

\subsection{Verskillende kulture, gebruike en gewoontes}

Bepaalde gedragspatrone, gebruike en gewoontes blyk sterker in sekere kulture teenwoordig te wees as in ander. So het daar in ons dag persepsies ontstaan van Switserse perfeksionisme, Franse estetika, Duitse tegnologie, Japannese elektronika, Spaanse en Italiaanse Casanovas en Don Juan's, of Amerikaanse grootheidswaan. Daar het byvoorbeeld geen sosiale stigma aan homoseksualiteit gekleef in China en Japan voordat die Westerse kultuur begin deurwerk het nie (Geldenhuys \& Du Toit 1979:254). Onder die Indiaanse en Eskimo stamme van die Noord Amerikaanse kontinent was die homoseksueel beskou as ' $\mathrm{n}$ shaman, of heilige man, nie as ' $n$ moreel verworpene of ' $n$ krimineel nie (Cole 1959:343-344). Volgens Nida (1954:107) word homoseksualiteit en masturbasie veral gevind in talle primitiewe kulture en word dit slegs onderdruk deur die feit dat vrouens meer geredelik beskikbaar is. Meeste kulture het homoseksuele gedrag nóg ontmoedig, nóg aangemoedig maar gewoon as ' $n$ gegewenheid aanvaar. Die kultuurhistoriese konteks van die antieke Griekse en Romeinse wêreld waarteen die Nuwe Testament ontstaan het, gee 'n kykie in hierdie destydse wêreld waarin die eerste Christenskrywers hulleself bevind het. Dis teen hierdie agtergrond wat hulle Christelike gedragskodes geformuleer het wat sou pas binne hulle verstaan van Christus en sy leer.

Die voorbeelde van die Griekse gode het onwillekeurig bygedra om ' $n$ soortgelyke morele standaard as dié van die gode onder hulle volgelinge te kweek. So het party Grieke byvoorbeeld homoseksualiteit geregverdig deur die ontvoering van die jong manlike Ganymede deur Zeus. Heilige prostitusie is weer bedryf deur die Afrodite kultus by die stad Korinte. Mens sou kon sê dat die Griekse gode ontstaan het as ' $n$ spieëlbeeld van menslike gedrag, wat weer op sigself gelei het tot ' $n$ model van nabootsing van die gode se gedrag deur die mense. Homoseksualiteit en manlike prostitusie was kenmerkend van die antieke Grieks-Romeinse samelewing. Veral gedurende die tydperk van die goue era van die antieke Griekse tydperk was homoseksualiteit nie net aanvaarbaar nie, maar selfs beskou as een van die hoekstene van die Griekse 
kultuur. In die Griekse kultuurgeskiedenis kan die verskynsel van homoseksualiteit waarskynlik, volgens Kittel et al (1995, Vol 6:583), teruggevoer word na die ou Griekse beskawing van Sparta, hoofsaaklik tussen die jare 800 en 500 vC. Sparta was die tuiste van homoseksualiteit wat hiervandaan wyd versprei het. Die Spartane was uitsluitlik militaristies ingesteld en die seleksie het reeds met geboorte begin. Enige kind wat swak gelyk het, is van die ouers afgeneem en is of op die berg Taygetus gelos om daar dood te gaan, of is van die steil kante van die berg afgegooi. Net die sterkste kinders het ' $n$ kans op oorlewing gehad. Seuns is van vroegs af fisies en psigies opgelei in die oorlogskuns en om goeie soldate te wees. Selfs meisies was fisies opgelei. Tot op die ouderdom van sewe jaar het seuns hoofsaaklik by hulle ma's groot geword. Dan was hulle weggeneem en in spesiale barakke van ' $n$ militêre skool geplaas. Hulle was gegroepeer in klein groepies wat deur ouer seuns gelei was en het ' $n$ harde lewe gehad onder die sorgvuldige oog van ' $n$ senior Spartaanse soldaat. Hulle opleiding was fisies straf en hulle het altyd kaalvoet geloop, dik warm wolklere in die somer gedra en dun mantels in die winter. Daar is uitermate sterk gefokus op die ontwikkeling van die fisiese liggaam en hierdie skole het "soldatefabrieke” geword. Die ouer seuns se opleiding was meer direk gerig op militêre oorlogvoering - waarvan twee jaar deurgebring was in die Kripteia, 'n soort geheime polisiediens. Op die ouderdom van twintig was elke jong man gekies om ' $n$ lid van 'n klub van vyftien lede te wees wat later sy betrokke afdeling in die weermag sou wees. Hier leef, eet en slaap hulle - selfs nadat hulle getroud is - en huwelike was nie toegelaat voor die ouderdom van dertig jaar nie. In hierdie klubs was alles gedeel. ' $n$ Vreemde Spartaanse gewoonte was ook die vrye blootstelling van die liggaam en selfs die aandrang op volledige naaktheid in die openbaar (Corsar, et al 1977:37-38; Cotterill 1922:95).

Later in Griekeland ontstaan daar "n "simposion", die "gasmaaltyd" of mans- drinkersgroep, wat hoofsaaklik die aristokratiese kultuur van die Griekse mans weerspieël het. Die simposion het plaasgevind in ' $n$ vertrek wat bekend gestaan het as die "manskamer" (androon) waar daar geëet en gedrink was en professionele vermaak aangebied was deur slawemeisies en slaweseuns. Daar was twee fokuspunte: toesprake en seks. Elke man het in ' $n$ bepaalde volgorde oor een of ander tema gepraat. Buite die familiekonteks het hierdie natuurlike emosies van liefde en seks 
hulle plek in die drinkersgroep gevind. Geleerdes is van mening dat hierdie die hoofrede vir die belang van homoseksualiteit in antieke Griekeland was, aangesien die simposion die fokus verskaf het vir interaksie met beide die "aardse" en die "geestelike" tipes - of dit nou met die mededrinkers was of met die slaweseuns. Selfs die groot Griekse skrywer, Plato, het homoseksuele liefde geïdealiseer in sy bespreking van die begrip Eros in werke soos sy "Simposium" (181B). Die hoogste vorm van liefde volgens hom was die liefde tussen man en man - wat nie alleen die hoogste vorm van emosionele bevrediging was nie, maar ook die basis gevorm het vir alle deugde en godsdienstige belewenisse (Geldenhuys \& Du Toit 1979:253). Xenophon vertel byvoorbeeld van vermaak by die simposium deur twee professionele slawekunstenaars wat beide akrobaties en eroties was. Die idealisering van hierdie emosies het waarskynlik gelei tot inspirasie van die hoogste vorme van liefde in die Europese literatuur. Die simposium was deel van 'n jeugkultuur wat ook in die gimnasium gestalte gekry het (Boardman et al 1998:218-220).

Ook die Griekse skrywer Sappho, 'n bekende vroue digter van die eiland Lesbos, idealiseer homoseksuele verhoudings in haar lirieke. Die bekendste hiervan is haar gedig "'n Himne aan Afrodite" - wat die godin van die liefde was. Sy het op Lesbos in ' $n$ godsdienstige gefundeerde kring, jong meisies voorberei op hulle latere huwelike (Kytzler 1986:106).

Daar is alreeds elders verwys ${ }^{1}$ na die feit dat in die antieke Griekse kultuur die fases van manlike seksualiteit byvoorbeeld streng voorgeskryf was en nie afhanklik was van individuele besluite nie. So moes die Griekse man deur bepaalde homoseksuele ervaringe beweeg op die regte tyd, met die regte mense en volgens die regte reëls (Cohen 1991:140-141,149). Dis daarom geen wonder dat iemand soos Alexander die Grote ook homoseksueel was nie.

As die fokus vir 'n oomblik wegskuif vanaf die Grieke na die Romeine, beskryf digters soos Virgilius en Ovidius in hulle odes die voordele van homoseksuele verbintenisse (Geldenhuys \& Du Toit 1979:253). Dis interessant om te lees uit die pen van die Romeinse skrywer Suetonius (Lives of the Caesars, 6.28) hoedat keiser Nero -

1 Sien my vorige bydrae oor "Identiteit en seksualiteit in die Nuwe Testament” in Verbum et Ecclesia 27 (2006), 131-154. 
wat regeer het in die tyd wanneer Paulus se briewe geskryf word op die punt gestaan het om met die jong seun, genaamd Sporus, in die huwelik te tree. Volgens Walvoord en Zuck (1985) was dit geen vreemde verskynsel onder die Romeinse keisers nie, aangesien 14 uit die eerste 15 keisers, insluitende Julius Ceasar, òf homoseksueel òf biseksueel was. Hadrianus - wat volgens die nuutste navorsing aan bewind was in die tyd toe Openbaring geskryf is - het deur die Romeinse Ryk gereis met sy jong manlike minnaar, Antinous. Wanneer hierdie minnaar in 130nC in die Nylrivier verdrink, word hy onmiddellik op bevel van Hadrianus vergoddelik. Die Christenskrywer Justinus die Martelaar reageer heftig in sy werk (Apologia I.29) teen hierdie vergoddeliking van Antinous. Sommige geleerdes huldig die hipotese dat Hadrianus se homoseksualiteit die agtergrond is waarteen 2 Petrus 2:7 (met ooreenkoms in Jud 6-7) geskryf is en wat handel oor die probleem van seksuele gemeenskap tussen mens en engele. Hierdie punt kan egter nie bewys word nie (Martin \& Davids 2000). Feit van die saak is, met hierdie voorbeeld van die Romeinse heersers het ' $n$ tydperk aangebreek waarin die staat groot belang ontwikkel het in voortplanting binne die patriargale familie en dat hulle dit uiteindelik moes aanmoedig, soms selfs begin voorskryf, in die sosiale belang omdat dit die geboortesyfer drasties begin beïnvloed het (Cahill 1995:290).

Veral in die lig van die eng verbinding tussen afgodediens en menslike gedrag onder die Grieke en Romeine, sou enige handeling wat op welke wyse ookal verbind kan word met afgodery, 'n taboe wees teen die agtergrond van die Joodse wet vir Jode en later ook vir spesifiek Joodse Christene.

\subsection{Die gebruik van terminologie}

'n Groot deel van die verwarring in die homoseksualiteitsdebat kan waarskynlik teruggevoer word na die gebruik van terminologie. Alhoewel net een woord as ' $n$ omvattende term gebruik word in Afrikaans, was verskillende terme in die antieke gebruik om verskeie aspekte van homoseksuele gedrag te beskryf. Ook in die huidige debat is daar klemverskille in die verstaan van die woord. As in gedagte gehou word dat die taalkundiges ons leer dat woorde op sigself nie betekenis het nie, maar dat ons woorde gebruik om betekenis te omskryf, dan word dit vinnig duidelik dat daar allerhande wanopvattings kan ontwikkel oor wat presies met die Afrikaanse term "homoseksualiteit" bedoel sou word. Anders gestel: 
Wat presies bedoel en verstaan verskillende mense vandag met die woord "homoseksualiteit" - en wat sou 'n term soos hierdie in die antieke tyd vir Christengelowiges beteken het? So is daar, onder andere, kritiek uit sommige kringe dat daar vandag onderskei behoort te word tussen "selibate homofiele" wat vroue homoseksuele (lesbiese verhoudings) sou insluit, maar aan die ander kant weer heteroseksuele wat in homoseksuele handelinge betrokke is, sou uitsluit.

Daar bestaan ' $n$ groot gevaar om hele leerstellings te bou rondom ' $n$ bepaalde woord of woorde. Dit was ' $n$ populêre metode van Skrifondersoek ' $n$ aantal jare gelede - so asof betekenis in ' $n$ enkele woord of woorde opgesluit sou lê en asof 'n grondige woordstudie sodanige betekenis kan ontsluit. Intussen het Skrifuitleggers die belang van die konteks waarin hierdie woorde voorkom, besef. Nie net die literêre konteks nie, maar ook die sosiohistoriese konteks behoort in ag geneem te word. Begrippe, terme en woorde behoort dus nie eenvoudig fragmentaries bestudeer te word nie, maar behoort van binne hulle konteks verstaan te word. Hoe breër en groter hierdie konteks, hoe meer verantwoordelik kan daar gepoog word om te verstaan wat ' $n$ antieke skrywer bedoel het. In die lig hiervan is dit dus noodsaaklik om die terme wat vertaal word met "homoseksualiteit" nie geïsoleerd van hulle literêre en sosiohistoriese kontekste waarin hulle voorkom, te bestudeer nie. Daar bestaan ' $n$ relatiewe groot hoeveelheid literatuur wat reeds aan hierdie terme en hulle kontekste op verskeie vlakke aandag gegee het. Dis nie die bedoeling van hierdie artikel om hierdie inligting eenvoudig hier te herhaal nie. Nogtans is dit nodig om wel uiters kursories die kontekste (literêr en sosio-histories), waarin hierdie uitsprake voorkom, kortliks so objektief as moontlik van nader te bekyk.

Daar is veral drie terme in die Nuwe Testament wat moontlik verwys na homoseksuele gedrag: pathos (wat 'n wye term is en na enige vorm van seksuele passie verwys het), malakos (die passiewe deelgenoot in ' $\mathrm{n}$ homoseksuele verhouding) en arsenokoites (die aktiewe deelgenoot in 'n homoseksuele verhouding).

- Pathos: Die woord is algemeen in gebruik in die Griekse literatuur en kom bykans 10,000 keer in al die Griekse dokumente voor. Dit word ook in die Nuwe Testament gevind in Romeine 1:26 ("skandelike drifte"); Kolossense 3:5 ("wellus") en 1 Thessalonisense 4:5 ("hartstog”). Dit word hoofsaaklik gebruik 
om na seksuele drange (passie) te verwys. Pathos was deur die Stoïsyne gebruik om die persoon te beskryf wat toegelaat het dat hy beheer word deur sy emosies en daarom nie rustigheid (apatheia) kon bereik nie. Al drie voorkomste in die Nuwe Testament (almal in die Pauliniese literatuur) word nie binne hierdie Stoïsynse verband gebruik nie, maar eerder in die sin van beskaamde passie wat ly tot seksuele losbandigheid (O’Brien 1982:182).

- Malakos: Hierdie woord kom vier keer in die Nuwe Testament voor: Matteus 11:8 (2x); Lukas 7:25 en 1 Korintiërs 6:9. In die eerste drie voorkomste dui dit op verfyndheid, en meer spesifiek op sagte, fyn klere wat delikaat is om aan te raak. Prohomoseksuele voorstaanders verkies hierdie interpretasie en meen dat die betekenis "sag" of "swak" op morele sagtheid of morele plooibaarheid sou dui en dat dit verwys na "mans wat saam bed toe gaan" of na manlike prostitusie. In 1 Korintiërs 6:9, dui dit na alle waarskynlikheid op die passiewe seksuele genoot in ' $n$ homoseksuele verhouding (sogenaamde verwyfde mans) teenoor arsenokoites wat op die aktiewe genoot gedui het in dieselfde konteks. Die term sou hier selfs vertaal kon word met "pleasure boys" of "rent boys" (Duffield 2004:113). Ook Geyser meen dat daar "baie getuienis in die destydse literatuur (is) van die pejoratiewe verwysing na ' $\mathrm{n}$ call-boy, die jeugdige wat vroulike styl, versiering en gedrag naboots en wat verval het in passiewe seksuele aktiwiteit vir plesier en vir betaling” (2002:1670). Verskillende Bybelvertalings verstaan die term op verskillende maniere en bied verskillende moontlikhede aan vir die vertaling hiervan: Manlike prostituut (New International Version); "effeminate" (meisie-agtig) (New American Standard Bible, American Standard Version, King James Version); Homoseksueel (New King James Version); (Homo)seksuele perverse persoon (Revised Standard Version, Revised English Bible, New English Bible); "self indulgent" (New Jerusalem Bible); seun prostituut, of "catamite" (skandjonge) (New American Bible). Winter (2001:117) herinner aan die mite waarin enigiemand wat die steen van 'n kinadion-vis sou aanraak, òf impotent sou word, òf "sag” sou word (malakizomai).

- Arsenokoites: Die woord kom een keer voor in die tydperk vóór die Nuwe Testament, te wete in die Scholia van Aristophanus (vers 153) waar daar na die lewenswyse van die Atheners verwys word as "verspot", want hulle is arsenokoitai en swak, of waardeloos. Die woord word ook gebruik in 1 Korintiërs 6:9 en 1 
Timoteus 1:10. Dis ' $\mathrm{n}$ selfstandige naamwoord en verwys waarskynlik in hierdie spesifieke kontekste na ' $n$ manlike homoseksuele persoon, en dan spesifiek die party in ' $n$ homoseksuele verhouding wat ' $n$ aktiewe rol sou neem gedurende homoseksuele geslagsverkeer. Grieks en verskeie ander tale het nie net een enkele woord vir homoseksuele geslagsverkeer nie, maar onderskei tussen die aktiewe en passiewe genote in ' $n$ homoseksuele verhouding met verskillende terme (Louw \& Nida 1988:772). Sommige is egter van mening dat die betekenis van arsenokoites in 1 Korintiërs 6:9 en 1 Timoteus 1:10 beperk is tot die van "manlike prostitusie" (masculi concubitores in die Latynse Vulgaat). Maar taalkundige bewyse om hierdie mening te steun ontbreek - onder andere omdat die woord uiters raar is in literatuur voor die Nuwe-Testamentiese tydperk. In die pseudepigrafiese literatuur soos die Sibileense Orakels (2:70-77) - wat dateer uit die tweede eeu $\mathrm{vC}$ tot die sewende eeu $\mathrm{nC}$ - en in die Handelinge van Johannes - wat dateer uit die tweede tot derde eeu $\mathrm{nC}$ - wil dit voorkom asof die term eintlik gebruik was in die sin van ekonomiese oortredings eerder as seksuele oortredings. As dit dan moontlik sou verwys het na een of ander vorm van ekonomiese uitbuiting deur seksuele dade, sou dit in die rigting van "pimping” kon dui (Duffield 2004:113). Die verwarring oor wat hierdie term presies beteken, word weer eens duidelik uit Bybelvertalings wat die term verskillend verstaan, enersyds as die aktiewe party gedurende geslagsverkeer in ' $n$ manlike homoseksuele verhouding, andersyds as manlike prostitusie, of ook as manlike homoseksuele pedofilie. Die woord word dus vanuit verskillende verstaansraamwerke met verskillende vertaalekwivalente vertaal in verskillende Bybelvertalings. Die Oosters Ortodokse kerk gebruik byvoorbeeld weer hierdie term in die breedste sin vir almal wat "n orgasme bereik of seksuele vreugde vind op enige manier wat nie plaasvind deur gewone seksuele omgang tussen man en vrou nie (Cole 1959:362). Dis duidelik dat daar nie eenstemmigheid is oor die betekenis van die woord nie en dat die verstaan hiervan subjektief gekleurd is. In die konteks van 1 Korintiërs 6:9 kan versigtig aanvaar word dat arsenokoites gebruik word binne ' $n$ pederastiese of ' $n$ homoseksuele pedofiele verhouding. Dieselfde woord word egter in 1 Timoteus 1:10 waarskynlik weer op ' $n$ meer generiese wyse gebruik en deur verskillende Bybelvertalings op verskillende maniere geïnterpreteer: sodomie (Revised Standard Version, die New Revised Standard Version, New King James Version); perverse seksuele gedrag (New International Version, New 
English Bible, Revised English Bible); praktiserende homoseksuele persone (New American Bible); homoseksuele (New Jerusalem Bible). Moffatt gebruik die terme "catamites" (skandjongens - van die naam Ganymede) en "sodomiete" terwyl die RSV die terme weer sien as hendiadis en beide vertaal as een begrip, te wete "homoseksuele", wat later weer hersien word as "seksuele perverse persone" (Freedman 1996:722). Uit hierdie reeks vertalings van dieselfde woord is daar dus geen twyfel nie dat die verskillende Bybelvertalings duidelik kies vir bepaalde terminologie ten einde bepaalde teologiese vertrekpunte te ondersteun! Volgens Wood \& Marshall (1996:479) blyk dit egter wel redelik duidelik te wees dat Paulus homoseksuele gedrag veroordeel in die mees algemene en teologiese breë terme wat hy ken, maar nie homoseksuele persone as sodanig nie (1996).

Veral die terme arsenokoites en malakos is die twee omstrede terme wat hewig onder diskussie is in die homoseksualiteitsdebat. Die meeste Bybelvertalings het dit met "effeminate" (meisieagtig) en met "homoseksuele” vertaal (Ukleja 1983:350). Die Nuwe Afrikaanse Bybelvertaling het beide terme tesame vertaal met "mense wat homoseksualiteit beoefen" (1 Kor 6:9). Daar is min twyfel dat Paulus die kombinasie van hierdie twee terme gebruik om ' $n$ (perverse) seksuele verhouding tussen twee manlike persone aan te dui - een die ouer manspersoon wat die aktiewe deelgenoot is en die ander die jong seun wat 'n passiewe rol inneem (moontlik teen betaling). Hierdie verhouding is primêr ' $n$ pederastiese verhouding. Meer hieroor later in Deel 2 by die bespreking van die betrokke Skrifgedeeltes. Volgens Boswell (1980:353) is daar uiteindelik geen rede om aan te neem dat Paulus met hierdie twee terme in 1 Korintiërs 6:9 na homoseksualiteit verwys het soos die term vandag in die algemene omgangstaal gebruik word nie. Boswell reken dat, wat hierdie terme ookal beteken het, hulle nie bepalend was in die vorming van die Christelike opinie aangaande die moraliteit van homoseksuele handelinge nie.

Winter (2001:114) is daarom tereg van mening dat Nuwe Testamentiese studies meer genuanseerd met seksuele terminologie behoort om te gaan as wat tans die geval is. Szesnat (1997:352) bevestig ' $\mathrm{n}$ terminologiese sensitiwiteit in hierdie verband. Ook Geyser (2002:1674) meen dat "ons vanuit 'n teologiese raamwerk sal moet sê dat eksegese oor hierdie paar tekste in die verlede, soms en in sommige kringe, té reglynig op die klank af toegepas is. Sake, 
selfs die naam en definisie van homoseksualiteit, is op anakronistiese wyse in tekste ingelees, vertaal en dan weer uitgelê". Die kompleksiteit van betekenismoontlikhede in die verskeie literêre en sosio-historiese kontekste waarbinne seksuele terminologie gebruik word, word algaande duideliker uit die voortgaande bespreking hieronder.

\subsection{Stereotipering en veralgemening}

'n Mens sou minstens drie verskillende soorte homoseksuele persone kon onderskei:

(a) Diegene wat deur biologiese faktore so gebore is en daarom gepredisposisioneerd homoseksueel is. Hierdie persone sou byna as "seksueel gestremd" beskryf kan word omdat hulle met ' $\mathrm{n}$ gebrek aan normale seksuele aangetrokkenheid tussen man en vrou sou gebore word - hoofsaaklik vanweë hormonale wanbalanse gedurende hulle fetale vormingsfases.

(b) Diegene wat deur omstandighede soos psigologiese afwykings of sosiale agtergronde so ontwikkel. Hierdie persone ontvlug in homoseksuele verhoudings omdat daar psigologiese en sosiale redes is vir hulle onvermoë om 'n normale aangetrokkenheid te ervaar vir 'n persoon van die teenoorgestelde geslag. Die hoofoorsake hiervan kan waarskynlik hoofsaaklik in die kind se vormingsjare teruggevind word.

(c) Diegene wat doelbewus ' $n$ keuse vir homoseksualiteit maak as gevolg van ' $n$ perverse lewenstyl, voorkeure vir biseksuele verhoudings, pederastie, of selfs as 'n 'modegier'.

Die eerste twee groepe sou moeilik vanuit die Skrif reglynig en onomwonde veroordeel kon word. 'n Pastorale pad van begrip en simpatie behoort saam met hulle gestap word. Talle eksperimente het bewys dat hulle uiters moeilik verander kan word omdat die oorsprong en keuse van hulle homoseksualiteit buite hulleself lê. Die laaste groep kan egter onomwonde en sonder enige twyfel vanuit die Skrif aangespreek word omdat die oorsprong en keuse van hulle homoseksuele gedrag binne hulleself lê en in hulle eie rasionele keuses te vinde is.

Om dus sondermeer alle homoseksuele persone vanuit die staanspoor te veroordeel, hulle oriëntasie as sonde te omskryf en die Skrif lynreg in al hierdie gevalle as 'n sweep te gebruik om hierdie "onding” met wortel en tak uit te roei, staan juis reglynig teenoor die 
boodskap en teologie van die Nuwe Testament. Die kerk kan juis daarom nie verval in 'n eenduidige en 'n eensydige antwoord ten opsigte van homoseksualiteit nie. Daar kan nie anders as gekwalifiseerd gepraat word oor homoseksuele oriëntasie en gedrag nie. Soos in alle etiese sake behoort ' $n$ verantwoordelike hantering van 'n etiese kwessie soos hierdie, ook individuele gevalle op sigself te hanteer. Die bedoeling van die Nuwe Testament was nie om tydlose antwoorde vir alle persone en alle gevalle in alle omstandighede en in alle plekke te gee nie. Mens sien dit byvoorbeeld duidelik nadat die besluit geneem is oor die besnydenis van nie-Jode wat tot die Christendom toegetree het en Paulus dan nogtans daarna vir Timoteus besny omdat dit strategies beter is vir die interaksie met die Joodse Christene.

\subsection{Die geskiedenis van ons kerklike tradisie oor kontroversiële gedrag-sake}

Wanneer dit kom by besluite oor etiese sake het die Christelike kerk 'n tradisie van worsteling. 'n Hele lys sake sou genoem kon word wat in die geskiedenis van die kerk in verskillende tydperke kontroversiëel was en waardeur die kerk met groot pyn moes worstel ten einde daaruit te kon groei. Die volgende sou as enkele voorbeelde kon dien uit die Nuwe Testamentiese tyd self:

- Die besnydenis of nie van nie-Joodse Christene (Hand 15:1-21; 1 Kor 7:18-19);

- Die eet van vleis wat aan afgode geoffer was (1 Kor 8);

- Die kwessie van trou of nie trou nie (1 Kor 7:8-9,25-40);

- Die kwessie van egskeiding (Mark 10:1-12; Matt 5:31-32; 19:1-9; Luk 16:18).

Later sou ook nog kwessies hierby kom soos die gebruik van drank, vrouens se dra van hoede in die erediens, Sondagviering op dieselfde basis as die Joodse Sabbat, apartheid, kerkverenigings, die gebruik van voorbehoedmiddels en die afgelope klompie jare ook homoseksualiteit. Hierdie rekord behoort die kerk te maan tot groter versigtigheid en sensitiwiteit om nie té maklik kategories te besluit wat reg en wat verkeerd is nie alvorens daar nie met genoegsame eerlikheid en so objektief as moontlik na alle aspekte van 'n etiese aangeleentheid soos hierdie, kennis geneem is nie. 


\section{KONKLUSIE}

Dit bly noodsaaklik om te vra hoedat die Nuwe Testament op ' $\mathrm{n}$ verantwoordelike manier gebruik kan word in die debat oor homoseksualiteit. Dis duidelik dat hierdie ' $n$ komplekse saak is wat gedryf word deur individue se subjektiewe menings omtrent die fenomeen self, nog lank voordat die Nuwe Testament opgetel word. Wanneer die Nuwe Testament dan ter hand geneem word, bepaal die vooropgestelde posisie van die leser die seleksie en die verstaan van die passasies. Dit blyk asof verskillende argumente ter sprake kom in die debat: emosionele argumente, sosiale druk, biologies-psigologiese argumente, Bybelse, teologiese en selfs tegniese argumente aangaande vergaderingsprosedures, word almal aangewend binne verskillende kontekste. Die feit van gegewe afwykings in die natuur, die voorkoms van die fenomeen in verskeie primitiewe en antieke kulture, asook die gebruik van 'n enkele term vir ' $n$ verskeidenheid aspekte wat alles onder die noemer van homoseksualiteit hanteer word, dra alles by tot hierdie komplekse labirint. Dit wil dus voorkom asof ' $n$ verantwoordelike gebruik van die Nuwe Testament in die homoseksualiteitsdebat slegs op 'n gedifferensieerde en gekwalifiseerde wyse sal moet geskied.

\section{Literatuurverwysings}

Boardman, J, Griffin, J \& Murray, O (eds) 1998. Greece and the Hellenistic World. Oxford: Oxford University Press.

Boswell, J 1980. Christianity, Social Tolerance and Homosexuality. Chicago: University of Chicago Press.

Burr, C 1996. A Separate Creation. New York: Hyperion. [21-36]

Cahill, L S 1995. Sex and Gender Ethics as New Testament Social Ethics, 272295, in: Rogerson, J W; Davies, M \& Daniel Caroll, M (eds), The Bible in Ethics. The Second Sheffield Colloquium (JSOT Suppl Series 207). Sheffield: Sheffield Academic Press.

Cohen, D 1991. Law, Sexuality, and Society: The Enforcement of Morals in Classical Athens. Cambridge: Cambridge University Press.

Cole, S O 1995. The Biological Basis of Homosexuality: A Christian Assessment. Journal of Psychology and Theology 23, 89-100.

Cole, W G 1959. Sex and Love in the Bible. New York: Association Press.

Corsar, P K, et al 1977. Discovering the Greeks. London: Edward Arnold Publishers.

Cotterill, H B 1922. Ancient Greece. London: George G Harrap \& Co. Ltd. 
Duffield, I K 2004. The Clear Teaching of the Bible? A Contribution to the Debate about Homosexsuality and the Church of England. Expository Times 115(4), 109-115.

Freedman, D N 1996. The Anchor Bible Dictionary. New York: Doubleday.

Geldenhuys, B P \& Du Toit, S I 1979. Psigopatologie. Academica: Pretoria.

Geyser, P A 2002. Bybelse getuienis oor homoseksualiteit - met ander oë gesien. HTS 58 (3-4), 1655-1677.

Greenberg, A S \& Bailey, J M 1993. Do Biological Explanations of Homosexuality Have Moral, Legal or Policy Implications? Journal of Sex Research 30, 245-251.

Hooker, E 1969. Parental relations and male homosexuality in patient and nonpatient samples. Journal of Consulting and Clinical Psychology 33, 140142.

Kittel, G, Friedrich, G \& Bromiley, G W 1995. Theological Dictionary of the New Testament. Translation of: Theologisches Worterbuch Zum Neuen Testament. Grand Rapids, Mich.: W.B. Eerdmans.

Kytzler, B 1986. Die Klassiker der griechischen Literatur. Dusseldorf: ECON Taschenbuch Verlag GmbH.

Looy, H 1995. Born Gay? A Critical Review of Biological Research on Homosexuality. Journal of Psychology and Christianity 14, 197-214.

Louw, J P \& Nida, E A (eds) 1988. s.v. ajsenokoi th, in: Greek-English Lexicon of the New Testament: Based on Semantic Domains. New York: United Bible Societies.

Martin, R P \& Davids, P H 2000. Dictionary of the Later New Testament and Its Developments. (electronic ed.) Downers Grove, IL: InterVarsity Press.

Morris, C G 1979. Psychology: An Introduction. New Jersey: Prentice-Hall.

Nida, E A 1954. Customs and Cultures. Anthropology for Christian Missions. Pasedena: William Carey Library.

O’Brien, P T 1982. Colossians, Philemon (Word Biblical Commentary 44). Waco, Texas: Word Books.

Schmidt, T E 1995. Straight and Narrow? Compassion and Clarity in the Homosexual Debate. Downers Grove, IL: InterVarsity [137-142]

Steyn, G J 2006. Identiteit en seksualiteit in die Nuwe Testament. Verbum et Ecclesia 27, 131-154.

Szesnat, H 1997. Human sexuality, history, and culture. Scriptura 62, 335-361.

Ukleja, P M 1983. The Bible and Homosexuality. Part 2: Homosexuality in the New Testament. BibSacr 140, 350-357.

Walvoord, J F \& Zuck, R B 1985. The Bible Knowledge Commentary : An Exposition of the Scriptures. Wheaton, IL: Victor Books. 
Winter, B W 2001. Roman Homosexual Activity and the Elite (1 Corinthians 6:9), in idem., After Paul Left Corinth. The Influence of Secular Ethics and Social Change, 110-120. Grand Rapids: Eerdmans.

Wood, D R W \& Marshall, I H (eds) 1996. s.v. Homosexuality, in: New Bible Dictionary. 3rd ed. Leicester: InterVarsity Press. 